\title{
Objective and Subjective Quality Characteristics of Pork Longissimus Muscle as a Function of the Ultimate $\mathrm{pH}$
}

\author{
Byung-Wook Cho, Maria Cynthia Oliveros ${ }^{1}$, Kyoung-Mi Park ${ }^{1}$, Kyoung-Tag Do, Ki-Hwan Lee ${ }^{2}$, \\ Kang-Seok Seo ${ }^{3}$, Jae-Gwan Choi ${ }^{2}$, Moon-Jun Lee ${ }^{4}$, In-Kyung Cho ${ }^{5}$, Byoung-Chul Choi ${ }^{6}$, \\ Kyeong-Seon Ryu ${ }^{1}$, and Inho Hwang ${ }^{1}$ * \\ Department of Animal Science, College of Life Science, Pusan National University, Miryang 627-706, Korea \\ ${ }^{I}$ Department of Animal Science and Institute of Rare Earth for Biological Application, \\ Chonbuk National University, Jeonju 561-756, Korea \\ ${ }^{2}$ National Institute of Animal Science, R.D.A., Cheonan 331-801, Korea \\ ${ }^{3}$ Department of Animal Resources Science, Sunchon National University, Sunchon 540-742, Korea \\ ${ }^{4}$ Department of Food Science and Biotechnology, Iksan 570-752, Korea \\ ${ }^{5}$ Department of Food and Nutrition Nambu University, Gwangju 506-824, Korea \\ ${ }^{6}$ Department of Statistical Informatics at Chonbuk National University, Jeonju 561-756 Korea
}

\begin{abstract}
The aim of the present study was to evaluate the variation in ultimate $\mathrm{pH}$ of commercial populations of pure-breed (Landrace, Duroc and Yorkshire) pig's longissimus muscles and their effect on objective meat quality traits and sensory characteristics. Fifty boars were sampled from 184 pigs, which were reared at three breeding farms and slaughtered at a commercial abattoir. The selection was determined based on ultimate $\mathrm{pH}$, and animals were segregated into three groups: low $\mathrm{pH}(\mathrm{pH} \leq 5.5, \mathrm{n}=13)$, medium $\mathrm{pH}(\mathrm{pH} 5.5$ to 5.6, $\mathrm{n}=18)$ and high $\mathrm{pH}(\mathrm{pH} \geq 5.6, \mathrm{n}=16)$. The breeds had no significant effects; however, pigs with a higher ultimate $\mathrm{pH}$ had significantly $(p<0.05)$ higher intramuscular fat content, lower level of polyunsaturated fatty acids, lower level of lipid oxidation and higher eating quality compared to those with lower ultimate $\mathrm{pH}$. As the ultimate $\mathrm{pH}$ increased, the relative proportion of $\mathrm{C} 14: 0, \mathrm{C} 16: 0$ and $\mathrm{C} 18: 1$ increased while $\mathrm{C} 18: 2 \mathrm{n} 6$ and $\mathrm{C} 20: 4 \mathrm{n} 6$ decreased. The present study demonstrates that the economic value of pigs can be characterized by the ultimate $\mathrm{pH}$ and/or intramuscular fat content. However, these results do not necessarily indicate that a high ultimate $\mathrm{pH}$ directly corresponds to high intramuscular fat content and vice versa.
\end{abstract}

Key words : pig, pH, intramuscular fat content, fatty acid, sensory traits

\section{Introduction}

It has been well documented that the rate and extent of $\mathrm{pH}$ decline have great effects on meat quality traits including water-holding capacity (Huff-Lonergan and Lonergan, 2005), tenderness (Savell et al., 2005), meat color (Holmer et al., 2009), and lipid oxidation (Hansen et al., 2004). Furthermore, ultimate $\mathrm{pH}$ of pork muscle is the most important single attribute influencing both eating quality (Lindahl et al., 2006; Huff-Lonergan and Lonergan, 2005) and fatty acid composition in particular genotype of pigs (Lundström et al., 1998; Zhang et al.,

\footnotetext{
*Corresponding author : Inho Hwang, Department of Animal Science and Institute of Rare Earth for Biological Application, Chonbuk National University, Jeonju 561-756, Korea. Tel: 8263-270-2605, Fax: 82-63-270-2605, E-mail: inho.hwang@ jbnu.ac.kr
}

2007).

Huff-Lonergan et al. (2002) reported significantly high simple correlation coefficient values between ultimate $\mathrm{pH}$ and tenderness, juiciness and flavor of pork longissimus muscle. A recent study reported by the same research group (Lonergan et al., 2007) demonstrated that ultimate $\mathrm{pH}$ between 5.8 and 5.5 had a significant effect on sensory properties of Berkshire, Chester White, Duroc, Hampshire, Landrace, Poland China, Spotted, and Yorkshire barrows and gilts while meats with a greater or lesser ultimate $\mathrm{pH}$ had little effect on sensory quality. On the other hand, an early study (Dransfield et al., 1985) reported that ultimate $\mathrm{pH}$ accounts for $5 \%$ of the variation in juiciness scores of pork. The study by Van Oeckel and Warnants (2003) failed to identify a significant difference in sensory characteristics between normal meat and PSE pork longissimus meat. Given these findings, ultimate $\mathrm{pH}$ 
across most commercial breeds appears to have significant effect on meat quality only when $\mathrm{pH}$ of meats ranges within relatively normal values, but not higher or lower. The fact, however, implies that difference in ultimate $\mathrm{pH}$ by a decimal unit (e.g., $\Delta 0.1$ ) can influence eating quality greatly. Studies also showed that ultimate $\mathrm{pH}$ as related to genotypes had significant effect on fatty acid composition. Zhang et al. (2007) reported that pigs with NN genotype (normal) had more C16:0 and C18:1 and less C18:2 and $\mathrm{C} 20: 4$ than those with $\mathrm{Nn}$ genotype. In addition, $\mathrm{RN}^{-}$ carrier gilts (PSE high glycolytic potential line) had the lowest amount of saturated fatty acid and MUFA, but had the highest amount of PUFA (Lundström et al., 1998).

In the Korean pig industry where guidelines for pre-, peri-, and post-slaughter procedures are not standardized, there are presumably many extrinsic factors that could affect ultimate $\mathrm{pH}$ including feeding scheme, slaughter weight and post-slaughter process (Park et al, 2009), as well as genetic factors (Hwang et al., 2004). For example, if the glycogen concentration of the muscle tissue is decreased due to feed restriction and stress prior to slaughter, the ultimate $\mathrm{pH}$ is higher than 5.5. On the other hand, even if the glycogen content in the muscle tissue is high enough to achieve $\mathrm{pH} 5.5$, the $\mathrm{pH}$ does not fall much lower than 5.4 under ordinary slaughter process due to inactivation of glycolytic enzymes under acidic environment (Young et al., 2004). However, if pigs are subjected to extreme stressors, the muscle will turn into PSE meat (Park et al., 2004).

The present study was designed to evaluate the variation in ultimate $\mathrm{pH}$ of commercial population of purebreed (Landrace, Duroc and Yorkshire) pigs' longissimus muscles and their effect on objective meat quality traits and sensory characteristics.

\section{Materials and Methods}

\section{Animals, experimental design and sampling}

Fifty boars (Landrace 17, Duroc 17 and Yorkshire 16) were selected from 184 pigs reared at three breeding farms and slaughtered at a commercial abattoir. Average live weight of the selected pigs were $100 \pm 12 \mathrm{~kg}$. All animals were fasted overnight and transported for $1 \mathrm{~h}$ to a commercial abattoir with minimal handling and transit stress. A lairage period of $6 \mathrm{~h}$ was followed and similar slaughter procedures were applied for all the pigs. All carcasses were hanged, chilled for $24 \mathrm{~h}$ and subsequently graded. A day after slaughter, $m$. longissimus thoracis et lumborum (LTL) were taken from the right side of the carcasses. The sample selection was determined on the basis of $\mathrm{pH}$ of the longissimus muscle on the $10^{\text {th }}$ rib of the right carcass at $24 \mathrm{~h}$ postmortem. All samples were frozen at $-20^{\circ} \mathrm{C}$ and transported to the Meat Science laboratory at CBNU, South Korea.

The frozen whole loin samples were cut into sub-sample sizes starting from the cranial end of the LTL (Fig. 1) depending on the type of analysis in the following order: $\mathrm{pH}$, sensory evaluation, intramuscular crude fat content, fatty acid composition, thiobarbituric acid reactive substance (TBARS), color, cooking loss, Warner Bratzler shear force (WBSF), moisture content, and protein solubility. Considering the number of population and range of $\mathrm{pH}$, pigs were segregated into three groups: low $\mathrm{pH}(\mathrm{pH}$ $\leq 5.5, \mathrm{n}=13)$, medium $\mathrm{pH}(\mathrm{pH} 5.5$ to $5.6, \mathrm{n}=18)$ and high $\mathrm{pH}(\mathrm{pH} \geq 5.6, \mathrm{n}=16)$. Sub-samples were vacuum-packed in oxygen impermeable polyethylene bags and stored at -

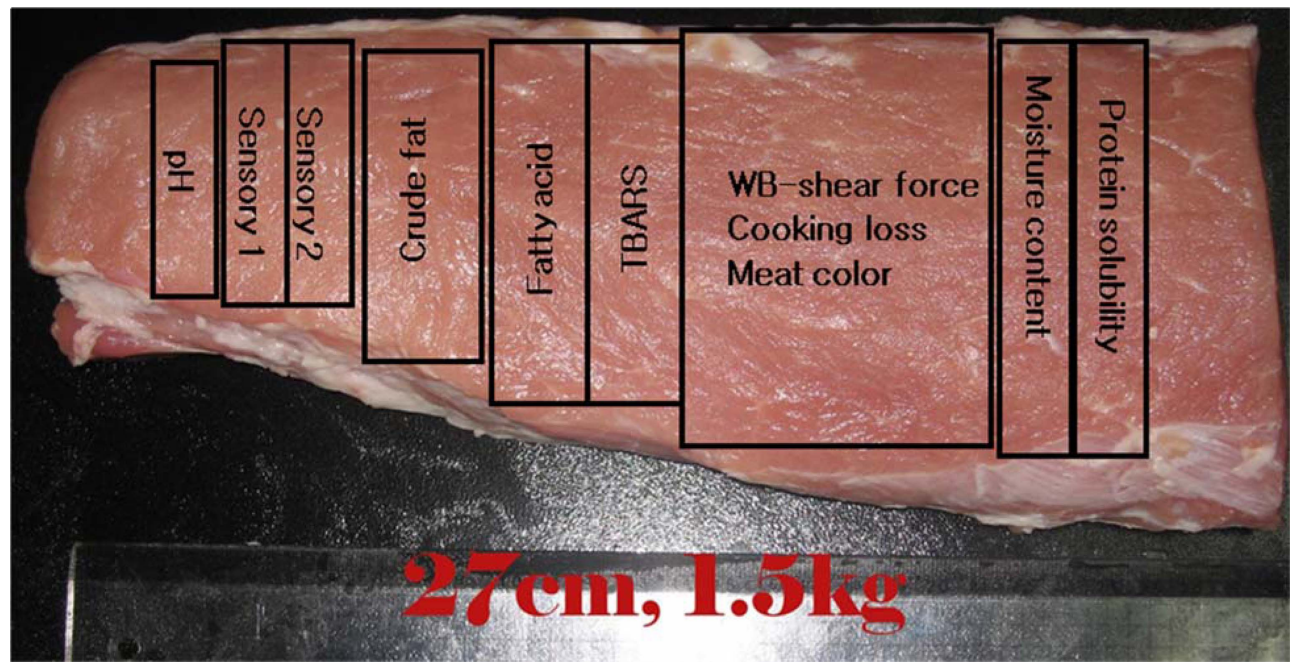

Fig. 1. Photograph of pig longissimus muscle and portion of sampling. 
$20^{\circ} \mathrm{C}$ until analysis.

\section{Objective meat quality traits}

The $\mathrm{pH}$ was determined in duplicates following the procedure of Bendall (1973) using a portable $\mathrm{pH}$ meter (Orion Model 301, USA). $5 \mathrm{mM}$ iodoacetate- $\mathrm{KCl}$ solution at a volume of 10 times the weight of the meat sample was added to 1 to $2 \mathrm{~g}$ of finely cut sample contained in a $50 \mathrm{~mL}$ conical tube. The mixture was homogenized twice for $30 \mathrm{~s}$ at $11,000 \mathrm{rpm}$ with $15 \mathrm{~s}$ break using the UltraTurrax T25B (IKA Works (Asia) Sdn, Bhd, Malaysia). The $\mathrm{pH}$ was measured at $25^{\circ} \mathrm{C}$ with an Orion $3 \mathrm{Star}$ (Thermo Electron Corp., USA) $\mathrm{pH}$ meter.

WBSF, cooking loss and meat color were determined on the same sample block which was thawed overnight at $2^{\circ}$ to $4^{\circ} \mathrm{C}$ in a chiller. Approximately $300 \mathrm{~g}$ block sample (approximately $5 \times 6 \times 7 \mathrm{~cm}, 6-7^{\circ} \mathrm{C}$ ) was placed in plastic bag and cooked in a pre-heated $70^{\circ} \mathrm{C}$ water bath for $1 \mathrm{~h}$ when core meat temperature reached $70^{\circ} \mathrm{C}$. Cooked samples were immediately cooled in an $18^{\circ} \mathrm{C}$ running water for 30 min and weighed. WBSF values were measured in an Instron Universal Testing Machine (Model 3342, Instron Corporation, USA) on six pieces core samples with 0.5 inch diameter using a crosshead speed of $400 \mathrm{~mm} / \mathrm{min}$ and a $40 \mathrm{kgf}$ load cell. The weights of the meat before and after cooking were recorded and the cooking loss was reported as weight loss expressed as percentage of the weight of sample before cooking. Objective meat color was evaluated with Konica Minolta Spectrophotometer CM-2500d with an $8 \mathrm{~mm}$ measuring port, D 65 illuminant and $10^{\circ}$ observer. Three measurements were taken on the cut surface of the meat that has been bloomed for 30 min. Hunter L, a, b values were recorded. The data presented are means of three measurements.

TBARS was assessed following the procedure of Buege and Aust (1978). A $2.5 \mathrm{~g}$ meat sample with $7.5 \mathrm{~mL}$ distilled water, $25 \mu \mathrm{L}$ saturated butylated hydroxyanisole (BHA) solution and $10 \mathrm{~mL}$ thiobarbituric acid/ trichloroacetic acid (TBA/TCA) solution was homogenized at 11,000 rpm for $15 \mathrm{~s}$ using an Ultra Turrax T25 (IKA Works (Asia) Sdn., Bhd., Malaysia). The volume of the homogenate was adjusted to $30 \mathrm{~mL}$ with a TBA/TCA solution and was immediately placed in ice. The tube containing the homogenate was immersed in a $90^{\circ} \mathrm{C}$ water bath for $15 \mathrm{~min}$. Thereafter, it was placed in ice to cool for $20 \mathrm{~min}$. Centrifugation at 3,000 rpm (SUPRA 21K, Hanil Science Industrial Co., Korea) for $10 \mathrm{~min}$ followed. About 1 to $1.5 \mathrm{~mL}$ supernatant was taken and the absorbance was measured at $531 \mathrm{~nm}$ in Ultrospec 2000 spectropho- tometer (Pharmacia Biotech, Cambridge, England). The TBARS value was calculated by multiplying the absorbance reading by 5.88. TBARS was expressed as mg malonaldehyde/kg meat sample.

Sarcoplasmic protein solubility measurements were carried out following the method of Warner et al. (1997). One gram muscle tissue sample was placed in a $50 \mathrm{~mL}$ conical tube and $10 \mathrm{~mL}$ of ice-cold $0.025 \mathrm{M}$ potassium phosphate buffer ( $\mathrm{pH}$ 7.2) was added. It was homogenized thrice, each with $4 \mathrm{~s}$ burst and $10 \mathrm{~s}$ break in between, with an UltraTurrax T25B (IKA Works (Asia) Sdn, Bhd, Malaysia) at 11,000 rpm. After keeping overnight in ice, samples were centrifuged at $1500 \mathrm{xg}$ at $4^{\circ} \mathrm{C}$ for $20 \mathrm{~min}$. About $1 \mathrm{~mL}$ supernatant was taken and protein concentration was determined and expressed as $\mathrm{mg} / \mathrm{g}$ tissue. The moisture content was measured in duplicates in an HR73 halogen moisture analyzer (Mettler-Toledo $\mathrm{GmbH}$, Switzerland) set at $105^{\circ} \mathrm{C}$. A $2.5 \mathrm{~g}$ minced meat sample was used for each measurement. Crude fat determination followed the Soxhlet method with petroleum ether as the extracting solvent (AMPC Meat and Livestock Australia). Five g of finely minced sample was placed in an extraction thimble, dried to constant weight at $102^{\circ} \mathrm{C}$ for $5 \mathrm{~h}$, cooled and placed in a Soxhlet extractor. Extraction was done with petroleum ether for $6 \mathrm{~h}$. Petroleum ether was evaporated at the end of extraction then the flask containing the fat extract was kept for $1 \mathrm{~h}$ in the drying oven set at $102^{\circ} \mathrm{C}$. The crude fat content of the lean sample was reported as the amount of extracted fat expressed as the percentage of the weight of the fresh sample.

\section{Fatty acid analysis and extraction}

Direct transesterification of fatty acid followed the procedure developed by Rule (1997). Thin slices of meat sample were freeze-dried for $48 \mathrm{~h}$ and pulverized. Five hundred mg of dried pork muscle was placed into a 20 $\mathrm{mL}$ headspace vial with silicone-lined cap. This was done in duplicates. Into each vial, $2 \mathrm{~mL}$ of $14 \%$ boron-trifluoride in methanol $(\mathrm{BDH}, \mathrm{BDH}$ Lab. Supplies, Poole, England) and $2 \mathrm{~mL}$ of methanol were added. The tube was sealed with a scrimp cap before it was placed in a heating block set at $80^{\circ} \mathrm{C}$. The tube was maintained at $80^{\circ} \mathrm{C}$ and vortex-mixed every $5 \mathrm{~min}$ for $2 \mathrm{~h}$. Cooling of the tubes soon followed and thereafter, $3 \mathrm{~mL}$ distilled water and $3 \mathrm{~mL}$ hexane were added. The tubes were capped and vortex-mixed for 15 . Centrifugation at $1000 \mathrm{~g}$ force for $5 \mathrm{~min}$ was done to accelerate phase separation. One $\mathrm{mL}$ of the upper hexane phase was transferred to 
GLC auto-sampler vials and was sealed. The extract was stored at $-20^{\circ} \mathrm{C}$ as gas chromatography was not done immediately.

Gas chromatograph Agilent Technologies 6890N Network GC System equipped with Agilent Technologies 7683B Series Injector and Agilent Technologies 5973 Network Mass Selective Detector was used to separate and identify the fatty acid components of the samples. GC separation of components was carried out on a fused silica capillary column $(30 \mathrm{~m} \times 0.25 \mathrm{~mm} \times 0.25 \mu \mathrm{m}$ film thickness, Supelcowax 10) at a split ratio of 100:1. Helium was used as the carrier gas. The inlet temperature was $250^{\circ} \mathrm{C}$ and the oven temperature program used was as follows: $50^{\circ} \mathrm{C}$ for $1 \mathrm{~min}$, raised to $200^{\circ} \mathrm{C}$ at the rate of $25^{\circ} \mathrm{C}$ per min, further increased to $230^{\circ} \mathrm{C}$ at $3^{\circ} \mathrm{C}$ per min. The temperature was held at $230^{\circ} \mathrm{C}$ for $15 \mathrm{~min}$. Detector temperature was $280^{\circ} \mathrm{C}$. Total running time was $35 \mathrm{~min}$. Individual fatty acids were expressed as percentage of the total fatty acids detected as fatty acid methyl esters.

\section{Sensory Evaluation}

The sensory evaluation was done following the protocols reported by Hwang et al. (2008). Given the experimental design for sensory evaluation, only 48 pigs out of 50 pigs used in the current study were assessed. Each pig was tested by 6 panels allocated in randomized block arrangement. Consumer panels consisted of 48 nontrained male and female university students. A total of 288 sensory samples were randomly allocated in 12 sets of four sessions; each session had 12 panelists and each panelist evaluated 6 samples.

The vacuum-packed and frozen sensory sample blocks were cut in frozen state. Approximately ten to twelve thin slices $(30 \mathrm{~mm} \times 30 \mathrm{~mm} \times 4 \mathrm{~mm})$ were sliced parallel to fiber direction across the sample block and strips were immediately placed in the freezer. 6 strips for each sample were finally chosen and placed in the labeled plastic sample bag depending on the designed session, panel and testing order. Samples were again vacuum-packed and immediately placed in the freezer set at $-20^{\circ} \mathrm{C}$ until use.

Samples allotted for evaluation were thawed for $30 \mathrm{~min}$ before the scheduled sensory session. The vacuumpacked meats were opened only when the samples are about to be cooked. Cooking was done on open tin-coated grill (surface temperature: $250-260^{\circ} \mathrm{C}$ ). Two sets of grill were used where each grill was set to cook 6 strips of samples. The twelve cooked samples were immediately dispensed on individual plates and served to the panelists. A $100 \mathrm{~mm}$ unstructured line scale with verbal anchors based on quantitative descriptive analysis was used, where the left anchor represented scoring of either tough, dry, extremely dislike the flavor or sample is extremely unacceptable. After evaluating each sample, the panelists were asked to refresh their mouth with the provided distilled drinking water and salt-free crackers.

\section{Statistical Analysis}

The data was analyzed using a general linear model (SAS Institute, Cary, NC, 2007). A preliminarily analysis was conducted to examine breed, farm and their interactions with ultimate $\mathrm{pH}$. When ultimate $\mathrm{pH}$ was included in the model as a covariate, the effects of breed and farm on meat quality traits showed no significance. Although these effects were not statistically significant the terms were retained in the final model to adjust these factors. Least square means were examined with pair difference test, and simple correlation coefficient between the quality traits of the pooled data were calculated using the Pearson procedure (SAS Institute, Cary, NC, 2007).

\section{Results and Discussion}

\section{Objective meat quality}

Results showed that $\mathrm{pH}$ values ranged from 5.38 to 5.81 with three distinctive $\mathrm{pH}$ groups. Preliminary analysis applying a mixed model with ultimate $\mathrm{pH}$ as a covariate showed that $\mathrm{pH}$ had significant effects on most meat quality traits. However, given that the values of the ultimate $\mathrm{pH}$ were clustered within three distinctive groups, the pigs were segregated into groups and used that groups as a fixed effect on the analysis of variance (Table 1).

Least square means for the groups were 5.44, 5.54 and 5.67 for lower $(\mathrm{pH} \leq 5.5, \mathrm{n}=13)$, middle $(\mathrm{pH} 5.5$ to 5.6 , $\mathrm{n}=18)$ and higher $(\mathrm{pH} \geq 5.6, \mathrm{n}=16)$ groups, respectively. To minimize variations in the rate and extent of $\mathrm{pH}$ decline as affected by pre- and post-slaughter procedures (Park $e t$ al., 2007; Park et al., 2004), feed restriction, lairage, and chilling regimes were standardized. Earlier study revealed a significant breed effect of Korean native black pig on pH decline (Hwang et al., 2004). However, the breeds (i.e., Landrace, Duroc and Yorkshire) used in the present study showed a limited effects on $\mathrm{pH}$ decline. Nevertheless, these factors were retained in the final models as fixed effects because, for the current population, breeds had a limited effect on meat quality traits, we reckon that the breed effects are confounded. The $\mathrm{pH}$ results indicated a considerable variation in ultimate $\mathrm{pH}$ of commercial boars 
and its significant effects on objective and subjective meat quality traits. As earlier noted, it is well known that the rate and extent of $\mathrm{pH}$ decline have great effects on meat quality traits including water-holding capacity (Huff-Lonergan and Lonergan, 2005), meat color (Holmer et al., 2009) and lipid oxidation (Hansen et al., 2004). In particular, ultimate $\mathrm{pH}$ greatly influences sensory attributes such as tenderness and juiciness for meats with $\mathrm{pH}$ between 5.8 and 5.5 (Lonergan et al., 2007). Considering the report of Lonergan et al. (2007) and the pH groups used in the present study, significant difference in carcass traits and eating quality between the $\mathrm{pH}$ groups was rather expected. However, it should be noted that in the present study, a difference of approximately one decimal point in $\mathrm{pH}$ values between groups (i.e., 5.44, 5.54 and 5.67 for low, medium and high, respectively) had significant $(p<0.05)$ effects on intramuscular fat content, cooking loss and WB-shear force (Table 1).

The most noticeable result was the significant $(p<0.05)$ linear increase in intramuscular fat content from lower to higher $\mathrm{pH}$ group. This relationship was evidenced by a simple correlation coefficient value of $0.57 \quad(p<0.001$, Table 4). Based on published literatures, it was not easy to understand the current relationship. Lonergan et al. (2007) reported that $\mathrm{pH}$ classification had very little effect on lipid content although pork in the intermediate $\mathrm{pH}$ class ( $\mathrm{pH}$ 5.5-5.8) had significantly higher lipid content than the greater $\mathrm{pH}$ class $(\mathrm{pH} \geq 5.95)$. In addition, intramuscular fat content did not differ between normal and PSE meat (Van Oeckel and Warnants, 2003), Similarly, crossbred pigs (Duroc $\times$ Landrace, Tia Meslan $\times$ Landrace) with various intramuscular fat levels in longis- simus muscle showed an identical ultimate $\mathrm{pH}$ (Fernandez et al., 1999).

In general, intramuscular fat content of pig's meat is affected by genetics, nutrition and environmental factors (Shi-Zeng and Su-Mei, 2009). The results of the present study differed with previous studies (Lonergan et al., 2007; Van Oeckel and Warnants, 2003 and Fernandez et al., 1999). These likely indicate that intrinsic and/or extrinsic factors related to intramuscular fat content are linked to ultimate $\mathrm{pH}$. In fact, numerous reports showed that NN genotype pig had greater lipid content than $\mathrm{Nn}$ pigs (Zhang et al., 2007; Maddock et al., 2002) or than nn genotype (Piedrafita et al., 2001). Because the halothane carrier pigs ( $\mathrm{Nn}$ and $\mathrm{nn}$ ) are prone to low $\mathrm{pH}$, higher lipid content can be obtained from NN (normal) genotype pig.

The benefit of high $\mathrm{pH}$ pork was evidenced in the stability of unsaturated fatty acids. Meat of the low $\mathrm{pH}$ group had a significantly higher TBARS value than meat of the medium $\mathrm{pH}$ and high $\mathrm{pH}$ groups. The results imply that lipid stability tended to decrease with decreasing $\mathrm{pH}$ of pork and that more lipid oxidation occurs at a lower ultimate $\mathrm{pH}$ (lower than 5.5). An early study (Yasosky et al., 1984) reported a critical ultimate $\mathrm{pH}$ value of 6.1 or higher for maximum inhibition of lipid oxidation. Similarly, Juncher et al. (2001) suggested a threshold value of approximately ultimate $\mathrm{pH} 5.8$ until which lipid oxidation continuously occurs. A higher risk of fat oxidation for meat with lower $\mathrm{pH}$ was also observed in frozen samples. Hansen et al. (2004) reported that lipid oxidation developed more significantly in pork with low ultimate $\mathrm{pH}$. Although $\mathrm{pH}$ range in each $\mathrm{pH}$ groups in the current study differed from the $\mathrm{pH}$ threshold for the minimum

Table 1. Objective quality traits of pork M. longissimus thoracis et lumborum as a function of ultimate pH levels

\begin{tabular}{|c|c|c|c|c|c|}
\hline \multirow{2}{*}{ Parameters } & \multicolumn{3}{|c|}{$\mathrm{pH} \mathrm{Level}^{1}$} & \multirow{2}{*}{$\begin{array}{c}\text { Average } \\
\text { standard error }\end{array}$} & \multirow{2}{*}{ F value } \\
\hline & Low $\mathrm{pH}(\mathrm{n}=13)$ & Medium $\mathrm{pH}(\mathrm{n}=18)$ & High $\mathrm{pH}(\mathrm{n}=16)$ & & \\
\hline $\mathrm{pH}$ & $5.44^{\mathrm{c}}$ & $5.54^{\mathrm{b}}$ & $5.67^{\mathrm{a}}$ & 0.01 & $99.53 * * *$ \\
\hline Moisture, $\%$ & $72.22^{\mathrm{a}}$ & $72.06^{\mathrm{a}}$ & $71.38^{\mathrm{b}}$ & 0.28 & $2.50 *$ \\
\hline Intramuscular Fat, \% & $1.67^{\mathrm{c}}$ & $2.77^{\mathrm{b}}$ & $3.67^{\mathrm{a}}$ & 0.33 & $8.08 * * *$ \\
\hline Hunter L & 59.00 & 59.47 & 58.16 & 1.01 & 0.45 \\
\hline Hunter a & 4.57 & 4.67 & 4.69 & 0.42 & 0.02 \\
\hline Hunter b & $15.50^{\mathrm{ab}}$ & $16.35^{\mathrm{a}}$ & $15.35^{\mathrm{b}}$ & 0.34 & $2.59 *$ \\
\hline Cooking loss, $\%$ & $21.65^{\mathrm{a}}$ & $20.86^{\mathrm{a}}$ & $19.37^{\mathrm{b}}$ & 0.60 & $3.46^{*}$ \\
\hline Warner Bratzler Shear Force, N & $23.25^{\mathrm{a}}$ & $21.68^{\mathrm{ab}}$ & $18.74^{\mathrm{b}}$ & 0.15 & $2.32 *$ \\
\hline Soluble Sarcoplasmic protein, $\mathrm{mg} / \mathrm{g}$ & 35.33 & 36.16 & 34.78 & 0.07 & 1.18 \\
\hline TBARS, mg MA/kg meat & $0.32^{\mathrm{a}}$ & $0.26^{\mathrm{b}}$ & $0.24^{\mathrm{b}}$ & 0.02 & $2.84 *$ \\
\hline $\mathrm{df}^{2}$ & & & & & $2 / 44$ \\
\hline
\end{tabular}

${ }^{1}$ Low $\mathrm{pH}, \mathrm{pH} \leq 5.5$; Medium $\mathrm{pH}, \mathrm{pH} 5.5$ to 5.6; High $\mathrm{pH}, \mathrm{pH}>5.6$.

${ }^{2}$ Numerator/Denominator degree of freedom.

${ }^{*} p \leq 0.05, * * p \leq 0.01, * * * p \leq 0.001$.

abc Means in the same row with different superscripts differed significantly $(p<0.05)$. 
Table 2. Consumer sensory characteristics of M. longissimus thoracis et lumborum (\% of total fatty acids) as a function of ultimate $\mathrm{pH}$ levels

\begin{tabular}{|c|c|c|c|c|c|}
\hline \multirow{2}{*}{ Parameters $^{2}$} & \multicolumn{3}{|c|}{ pH Level ${ }^{1}$} & \multirow{2}{*}{$\begin{array}{c}\text { Average } \\
\text { standard error }\end{array}$} & \multirow{2}{*}{$\mathrm{F}$ value } \\
\hline & Low $\mathrm{pH}(\mathrm{n}=13)$ & Medium $\mathrm{pH}(\mathrm{n}=18)$ & High $\mathrm{pH}(\mathrm{n}=16)$ & & \\
\hline Tenderness & $50.24^{\mathrm{b}}$ & $58.79^{\mathrm{a}}$ & $61.36^{\mathrm{a}}$ & 2.64 & $4.20^{*}$ \\
\hline Juiciness & $51.92^{\mathrm{b}}$ & $62.44^{\mathrm{a}}$ & $61.01^{\mathrm{a}}$ & 2.73 & $3.86^{*}$ \\
\hline Flavor & $56.73^{\mathrm{b}}$ & $61.42^{\mathrm{ab}}$ & $63.48^{\mathrm{a}}$ & 1.98 & $2.66^{*}$ \\
\hline Overall acceptability & $50.64^{\mathrm{b}}$ & $59.01^{\mathrm{a}}$ & $61.70^{\mathrm{a}}$ & 2.70 & $3.95^{*}$ \\
\hline
\end{tabular}

${ }^{1}$ Low $\mathrm{pH}, \mathrm{pH} \leq 5.5 ;$ Medium $\mathrm{pH}, \mathrm{pH} 5.5$ to 5.6; High $\mathrm{pH}, \mathrm{pH}>5.6$.

${ }^{2}$ Tenderness, 0 (not tender) to 100 (very tender); Juiciness, 0 (not juicy) to 100 (very juicy); Flavor, 0 (dislike extremely) to 100 (like extremely); Overall acceptability, 0 (dislike extremely) to 100 (like extremely).

${ }^{3} \mathrm{df}$ : Numerator/Denominator degree of freedom.

$* p<0.05, * * p<0.01, * * * p<0.001$.

${ }^{\mathrm{abc}}$ Means in the same row with different superscripts differed significantly $(p<0.05)$

oxidation of fatty acids, limited oxidation of meat with high $\mathrm{pH}$ was evident.

Although the simple correlation coefficient between $\mathrm{pH}$ and TBARS was not significant $(p>0.05)$ (Table 4), the small difference in $\mathrm{pH}$ between the three groups showed a significant difference in TBARS measurement. Given that the samples were vacuum packed and not chilleraged, the result in part (if not) can be attributed to differences in the fatty acid composition of pork in the three $\mathrm{pH}$ groups. Fatty acid composition showed that polyunsaturated fatty acid contents decreased as the ultimate $\mathrm{pH}$ of pork increased (Table 3), thus there were likely less substrate for lipid oxidation resulting in lower TBARS value. A further discussion is in the following section.

WB-shear force indicated that toughness was significantly $(p<0.05)$ reduced for the higher $\mathrm{pH}$ meat (Table 1$)$.

Table 3. Fatty acid composition of M. longissimus thoracis et lumborum (\% of total fatty acids) as a function of ultimate $\mathrm{pH}$ levels

\begin{tabular}{|c|c|c|c|c|c|}
\hline \multirow{2}{*}{$\begin{array}{l}\text { Parame- } \\
\text { ters }\end{array}$} & \multicolumn{3}{|c|}{ pH level $^{1}$} & \multirow{2}{*}{$\begin{array}{c}\text { Average } \\
\text { standard } \\
\text { error }\end{array}$} & \multirow[b]{2}{*}{$F$ value } \\
\hline & $\begin{array}{c}\text { Low } \mathrm{pH} \\
(\mathrm{n}=13)\end{array}$ & $\begin{array}{c}\text { Medium } \\
\mathrm{pH}(\mathrm{n}=18)\end{array}$ & $\begin{array}{c}\text { High pH } \\
(\mathrm{n}=16)\end{array}$ & & \\
\hline $\mathrm{C} 14: 0$ & $1.35^{\mathrm{b}}$ & $1.53^{\mathrm{ab}}$ & $1.66^{\mathrm{a}}$ & 0.10 & $2.40 *$ \\
\hline C16:0 & $23.34^{\mathrm{b}}$ & $23.73^{\mathrm{ab}}$ & $24.60^{\mathrm{a}}$ & 0.38 & $2.81^{*}$ \\
\hline C16:1 & 2.70 & 2.90 & 2.89 & 0.26 & 0.19 \\
\hline C18:0 & 13.36 & 14.21 & 14.11 & 0.64 & 0.49 \\
\hline C18:1 & $37.47^{\mathrm{b}}$ & $39.29^{\mathrm{ab}}$ & $41.61^{\mathrm{a}}$ & 1.20 & $2.80 *$ \\
\hline C18:2n6 & $16.73^{\mathrm{a}}$ & $14.19^{\mathrm{ab}}$ & $11.61^{b}$ & 1.20 & $4.21 * *$ \\
\hline $\begin{array}{l}\mathrm{C} 20: 4 \mathrm{n} 6 \\
\mathrm{df}^{2}\end{array}$ & $4.79^{\mathrm{a}}$ & $3.66^{\mathrm{ab}}$ & $2.86^{\mathrm{b}}$ & 0.50 & $\begin{array}{l}3.40 * * \\
2 / 44\end{array}$ \\
\hline
\end{tabular}

${ }^{1}$ Low pH, pH $\leq 5.5$; Medium $\mathrm{pH}, \mathrm{pH} 5.5$ to 5.6; High $\mathrm{pH}, \mathrm{pH}>5.6$.

${ }^{2}$ Numerator/Denominator degree of freedom.

$* p \leq 0.05, * * p \leq 0.01, * * * p \leq 0.001$

abc Means in the same row with different superscripts differed significantly $(p<0.05)$.
The underlying mechanism(s) is not clear as differences in both physical and biological status of meat samples between the $\mathrm{pH}$ groups were not determined. However, this is likely partly related to the greater amount of intramuscular fat content for the higher $\mathrm{pH}$ group. Thompson (2002) discussed that the major function of intramuscular fat in the textural property of meat includes reduced number of muscle fiber within a certain dimension. In other words, the muscle tissue with higher fat content has a lower resistance to shearing force because of the dilution

Table 4. Simple correlation coefficient $(r)$ between $p H$ and the objective and subjective quality traits of pork $M$. longissimus thoracis et lumborum

\begin{tabular}{lc}
\hline \multicolumn{1}{c}{ Parameter } & Correlation coefficient \\
\hline Moisture & $-0.333^{*}$ \\
Intramuscular fat & $0.569^{* * *}$ \\
Hunter L* & 0.013 \\
Hunter a* & -0.038 \\
Hunter b* & -0.085 \\
Cooking loss & $-0.343^{*}$ \\
Warner Bratzler shear force & $-0.328^{*}$ \\
Soluble sarcoplasmic protein & -0.013 \\
TBARS & -0.256 \\
C14:0 & $0.365^{* * *}$ \\
C16:0 & $0.294^{*}$ \\
C16:1n7 & 0.121 \\
C18:0 & 0.073 \\
C18:1 & $0.334^{*}$ \\
C18:2n6 $20: 4 n 6$ & $-0.401^{* *}$ \\
Tenderness & $-0.348^{*}$ \\
Juiciness & $0.392^{* *}$ \\
Flavor & $0.286^{*}$ \\
Overall Acceptability & $0.320^{*}$ \\
Rating & $0.417^{* *}$ \\
\hline
\end{tabular}

$* p<0.05, * * p<0.01, * * * p<0.001$. 
of fibrous protein by soft fat (Shi-Zheng and Su-Mei, 2009). Furthermore, the accumulation of fat in the perimysial connective tissues forces the muscle bundles apart thus opening up the muscle structure (Wood et al., 1999). In addition, less cooking loss for the high $\mathrm{pH}$ group can be related to a tender texture of cooked sample. In pig studies within a similar fat content group, Van Laack et al. (2001) pointed out that the relationship of ultimate $\mathrm{pH}$ with tenderness is dependent on genetics. It was observed that in meat from Hampshire pigs, WBshear force increased linearly as ultimate $\mathrm{pH}$ increased, whereas in Duroc and Berkshire pork, WB-shear force decreased as ultimate $\mathrm{pH}$ increased. WB-shear values in the current study are all negatively correlated with tenderness $(r=-0.478)$, juiciness $(r=-0.164)$, flavor $(r=-0.119)$ and overall acceptability ( $\mathrm{r}=-0.150)$. It should be emphasized that the current result again demonstrated that WB-shear force largely reflects tenderness and approximately $50 \%$ variation in sensory tenderness, but not in other sensory traits such as juiciness and flavor.

The pork in the high $\mathrm{pH}$ group had significantly $(p<$ 0.05 ) smaller cooking losses than the low and medium $\mathrm{pH}$ groups. The cooking loss for medium $\mathrm{pH}$ was lower but not significantly different from meat with low $\mathrm{pH}$. These confirm previous findings that water binding ability of muscle proteins are reduced with decreasing $\mathrm{pH}$, resulting in increased cooking loss (Aaslyng et al., 2003). The $\mathrm{pH}$ affects the distance between the myofilaments and distribution of water due to its effect on electrostatic repulsion (Aaslyng et al., 2003; Mortensen et al., 2006; Bertram et al., 2002). It was modeled that fiber and fiber bundles shrink when their constituent myofibrils shrink thus giving rise to extracellular compartments around fibers and fiber bundles in which meat juice accumulates. Furthermore, lateral shrinkage of the filament lattice is brought about by a $\mathrm{pH}$-fall closer to the isoelectric point, rigor contraction and myosin denaturation (Offer and Knight, 1988; Offer and Cousins, 1992). The results of this study demonstrated the importance of muscle $\mathrm{pH}$ for water holding capacity and consequently cooking loss.

On the other hand, less cooking loss for the higher $\mathrm{pH}$ group was less likely related to protein denaturation because sarcoplasmic protein solubility did not differ between the three $\mathrm{pH}$ groups. An early study (Joo et al., 1999) reported that sarcoplasmic protein solubility increases for pig longissimus muscle with a higher ultimate pH. In a similar notion, Channon et al. (2000) observed that solubility of sarcoplasmic, myofibrilllar and total protein was significantly influenced by halothane geno- type, with halothane carrier pigs exhibiting lower sarcoplasmic, myofibrillar and total protein solubility compared with homozygous normal pigs. Early postmortem events including rate and extent of $\mathrm{pH}$ decline, proteolysis and even protein oxidation are keys in influencing the ability of meat to retain moisture (Huff-Lonergan and Lonergan, 2005). In addition, a number of studies have shown that a fast rate of $\mathrm{pH}$ decline with a slow decline in temperature results in protein denaturation and thereby causing a decrease in protein solubility (Rees et al., 2003). The rate and extent of $\mathrm{pH}$ and temperature decline were not determined, but current result implies that $\mathrm{pH} /$ temperature window during rigor development was not great enough to be reflected in the measurement of sarcoplasmic protein solubility. This is more likely because pre-, peri-, and post-slaughter procedures were standardized in the present study.

Hunter $\mathrm{L}$ and a values were similar in all $\mathrm{pH}$ groups. Although Hunter b was significantly higher in the medium $\mathrm{pH}$ than the high $\mathrm{pH}$ group, numerical difference was very limited. Lower muscle $\mathrm{pH}$ is believed to increase free water at the cell surface resulting in an increased reflectance giving the meat a lighter appearance (Pearson and Dutson, 1985; Rees et al., 2003). Lindahl et al. (2006) observed that the combination of high temperature and low $\mathrm{pH}$ early postmortem increased lightness and yellowness, which is ascribed to inactivation of oxygen-consuming enzymes and protein denaturation. Ashmore et al. (1972) explained that the higher $a$ and $b$ values at low $\mathrm{pH}$ is due to the inactivation of mitochondria that leads to the inhibition of oxygen consumption. More oxygen is available for oxygenation of myoglobin thus the meat has a deeper layer of oxymyoglobin. Nevertheless, an identical color dimension between the $\mathrm{pH}$ groups indicated these differences do not influence objective meat color.

\section{Sensory characteristics and fatty acid composition}

Meat in the low $\mathrm{pH}$ group showed inferior eating quality than the other groups for all aspects determined (i.e, tenderness, juiciness, flavor, and overall acceptability, Table 2). As pointed out earlier, the higher eating quality coincided with higher lipid content and lower cooking loss. The positive effect of intramuscular fat content on eating quality has been obvious, but the magnitude of its effects on individual sensory characteristics (i.e, tenderness, flavor and juiciness) has been controversial. ShiZheng and Su-Mei (2009) reported that intramuscular fat content below the optimum range of $2.5-3 \%$ diminishes 
eating quality whereas a higher fat content does not further improve sensory quality. Other researches, however, have demonstrated that a higher fat content improved more the eating quality (Eikelenboom and Hoving-Bolink, 1994; Goodwin and Burroughs, 1995). Eating quality is not determined by a single parameter, but is confounded by numerous factors including fat content and water holding capacity. Taking only lipid content and ultimate $\mathrm{pH}$, the current consumer panel indicated that intramuscular fat content of 2.8 and 3.7 did not differ while $1.7 \%$ had inferior quality. In addition, meats from medium and high $\mathrm{pH}$ groups were similar. This may indicate that a larger difference in $\mathrm{pH}$ and lipid content was required to distinguish flavor difference.

There were significant positive correlations between intramuscular fat content and tenderness $(\mathrm{r}=0.431)$, juiciness $(r=0.267)$, flavor $(r=0.380)$ and overall acceptability $(\mathrm{r}=0.383)$. The tendency of the relationships between ultimate $\mathrm{pH}$ and sensory traits were also observed (Table 4). This re-confirmed the importance of lipid content and ultimate $\mathrm{pH}$ on sensory quality and was consistent with the previous study of Eikelenboom et al. (1996) who reported a 33\% correlation between juiciness and lipid fat content. More recently, Lonergan et al. (2007) reported that pork belonging to high $\mathrm{pH}$ classes $(\mathrm{pH} \geq 5.80$ to 5.95 and $\mathrm{pH} \geq 5.95$ ) had higher juiciness and tenderness scores than the low $\mathrm{pH}$ class $(\mathrm{pH}<5.50)$.

With the increase in ultimate $\mathrm{pH}$, initial examination showed a clear tendency that the relative proportions of C14:0, C16:0 and C18:1 increased whereas C18:2n6 and C20:4n6 decreased, although significant differences were observed only between low and high $\mathrm{pH}$ groups for five fatty acids. We are unaware of available literature reporting relationship between $\mathrm{pH}$ and fatty acid composition, but a number of genetic studies showed that pigs susceptible to low ultimate $\mathrm{pH}$ showed a similar proportion of fatty acid composition with our current data. Zhang et al. (2007) reported that pigs with $\mathrm{NN}$ genotype (normal) had more C16:0 and C18:1 and less C18:2 and C20:4 than Nn pigs. Furthermore, $\mathrm{RN}^{-}$carrier gilts had the lowest amount of saturated fatty acid and MUFA, but had the highest amount of PUFA (Lundström et al., 1998). It has been well known that meat from $\mathrm{RN}^{-}$pigs has characteristically high glycolytic potential and consequently low ultimate $\mathrm{pH}$.

As earlier discussed, the breed effect on lipid content and fatty acid composition was examined during the preliminary analysis, but no statistically significant effects were noted. On the other hand, it was observed that a higher level of polyunsaturated fatty acid was related to low $\mathrm{pH}$ group while a lower level of other fatty acids was related to high $\mathrm{pH}$ group which, relates to low and high intramuscular fat groups, respectively. Wood and Enser (1997) have reported that there is a strong correlation between the amount of fat and the concentration of polyunsaturated fatty acids. Linoleic acid (C18:2) is mainly derived from feeds and are readily incorporated into adipose tissues of pigs. The proportion of C18:2 and its derivative C20:4 declines while the proportion of synthesized fatty acids increases as fat deposition proceeds thus a dilution effect is created (Wood and Enser, 1997; Wood et al., 2008). Similarly Lonergan et al. (2007) reported the simple correlation coefficients between intramuscular fat content and C14:0 ( $\mathrm{r}=0.63), \mathrm{C} 16: 0(\mathrm{r}=0.44), \mathrm{C} 16: 1$ ( $\mathrm{r}$ $=0.41)$ and $\mathrm{C} 18: 1(\mathrm{r}=0.52), \mathrm{C} 18: 2(\mathrm{r}=-0.59)$ and $\mathrm{C} 20: 4(\mathrm{r}$ $=-0.55$ ). The results of the study showed that higher $\mathrm{pH}$ pigs contained less level of polyunsaturated fatty acid. However, the underlying mechanism(s) for this relationship is not clear.

In the case of flavor, it is particularly noted that consumers preferably marked greater scores for higher $\mathrm{pH}$ group, although statistical difference was observed only between low and high groups. This implies that high levels of polyunsaturated fatty acids for pigs with low fat content result in unfavorable flavor and that concurred with high level of TBARS.

\section{Implications}

Pigs with higher ultimate $\mathrm{pH}$ resulted in higher intramuscular fat content, lower level of unsaturated fatty acids, lower level of lipid oxidation and higher eating quality compared to those with lower ultimate $\mathrm{pH}$. Some carcass traits and sensory characteristics did not differ between the low and medium $\mathrm{pH}$ groups, and between the medium and high $\mathrm{pH}$ groups, but the high $\mathrm{pH}$ group showed overall superior carcass and eating qualities and fat stability than the low $\mathrm{pH}$ group. The result of the present study implies that higher economic value of pigs can be characterized by a high ultimate $\mathrm{pH}$ and/or high intramuscular fat content. For the current population, breeds had a limited effects on meat quality traits, but the results are likely confounded by breed effects, On the other hand, it does not follow that high ultimate $\mathrm{pH}$ results in high intramuscular fat content and vice versa. Furthermore, $\mathrm{pH}$ threshold between groups was experimental comparisons and does not reflect $\mathrm{pH}$ window for meat quality. 


\section{Acknowledgement}

We would like to acknowledge the financial support from the Rural Development Administration for the current study and preparation of the manuscript.

\section{References}

1. Aaslyng, M. D., Bejerholm, C., Ertbjerg, P., Bertram, H. C., and Andrsen, H. J. (2003) Cooking loss and juiciness of pork in relation to raw meat quality and cooking procedure. Food Qual. Prefer. 14, 277-288.

2. Allison, C. P., Bates, R. O., Booren, A. M., Johnson, R. C., and Doumit, M. E. (2003) Pork quality variation is not explained by glycolytic enzyme capacity. Meat Sci. 63, 1722.

3. Ashmore, C. R., Parker, W., and Doerr, L. (1972) Respiration of mitochondria isolated from dark-cutting beef: postmortem changes. J. Anim. Sci. 34, 46-48.

4. Bendall, J. R. (1973) Postmortem changes in muscle. In: Structure and function of muscle, 2nd ed., Vol. II, Part 2, Bourne, G. H. (ed), Academic Press, New York.

5. Bertram, H. C. and Aaslyng, M. D. (2002) Relationship between meat structure, water mobility and distribution - a low field NMR study. J. Agri. Food Chem. 50, 824-829.

6. Buege, J. A. and Aust, J. D. (1978) Microsomal lipid peroxidation. Methods in Enzymol. 52, 302-309.

7. Channon, H. A., Payne, A. M., and Warner, R. D. (2000) Halothane genotype, pre-slaughter handling and stunning method all influence pork quality. Meat Sci. 56, 291-299.

8. Dransfield, E. and Lockyer, D. K. (1985) Cold-shortening toughness in excised pork. Meat Sci. 13, 19-32.

9. Eikelenboom, G. and Hoving-Bolink, A. H. (1994) The effect of intramuscular fat on eating quality of pork. In: Proceedings $40^{\text {th }}$ International Congress of Meat Science and Technology, The Hague, The Netherlands.

10. Estrade, M., Vignon, X., and Monin, G. (1993) Effect of the $\mathrm{RN}^{-}$gene on the ultrastructure and protein fractions in pig muscle. Meat Sci. 35, 313-319.

11. Fernandez X., Monin G., Talmart, A., Mourot, J., and Lebret, B. (1999) Influence of intramuscular fat content on the quality of pig meat: I. Composition of the lipid fraction and sensory characteristics of $m$. Longissimus lumborum. Meat Sci. 53, 59-65.

12. Fisher, P., Mellett, F. D., and Hoffman, L. C. (2000) Halothane genotype and pork quality. 1. Carcass and meat quality characteristics of three halothane genotypes. Meat Sci. 54, 97-105.

13. Fortin, A., Robertson, W. M., and Tong, A. K. W. (2005) The eating quality of Canadian pork and its relationship with intramuscular fat. Meat Sci. 69, 297-305.

14. Goodwin, R. and Burroughs, S. (1995) Genetic evaluation terminal line program results. National Pork Producers Council, Des Moines, IA.

15. Hamilton, D. N., Ellis, M., Miller, K. D., McKeith, F. K., and
Parrett, D. F. (2000) The effect of the Halothane and Rendement Naple genes on carcass and meat quality characteristics of pigs. J. Anim. Sci. 78, 2862-2867.

16. Hamilton, D. N., Miller, K. D., Ellis, M., McKeith, F. K., and Wilson, E. R. (2003) Relationships between longissimus glycolytic potential and swine growth performance carcass traits and pork quality. J. Anim. Sci. 81, 2206-2212.

17. Hansen, E., Juncher, D., Henckel, P., Karlsson, A., Bertelsen, G., and Skibsted, L. H. (2004) Oxidative stability of chilled pork chops following long term freeze storage. Meat Sci. $\mathbf{6 8}$, 479-484.

18. Holmer, S. F., McKeith, R. O., Boler, D. D., Diger, A. C., Eggert, J. M., Petry, D. B., Mckeith, F. K., Jones, K. L., and Killefer, J. (2009) The effect of $\mathrm{pH}$ on shelf-life of pork during aging and simulated retail display. Meat Sci. 82, 86-93.

19. Huff-Lonergan, E. and Lonergan, S. M. (2005) Mechanisms of water-holding capacity of meat: The role of postmortem biochemical and structural changes. Meat Sci. 71, 194-204.

20. Huff-Lonergan, E., Baas, T. J., Malek, M., Dekkers, J. C. M., Prusa, K., and Rothschild, M. F. (2002) Correlations among selected pork quality traits. J. Anim. Sci. 80, 617-627.

21. Hwang, I. H., Polkinghorne, R., Lee, J. M. Lee, and Thompson, J. M. (2008) Demographic and design effects on beef sensory scores given by Korean and Australian consumers. Aust. J. Exptl. Agri. 48, 1387-1395.

22. Hwang, I. H., Park, B. Y., Kim, J. H. Cho, S. H., and Lee, J. M. (2004) Effects of pre-slaughter fasting and chiller ageing on objective meat quality in longissimus dorsi, biceps femoris, and triceps brachii muscles of Korean native black pigs. Anim. Sci. Biot. 46, 405-414

23. Johansson, L., Lundström, K., and Jonsäll, A. (2002) Effects of RN genotype and silage feed on fat content and fatty acid composition of fresh and cooked pork loin. Meat Sci. 60, 1724.

24. Joo, S. T., Kauffmann, R. G., Kim, B. C., and Park, G. B. (1999) The relationship of sarcoplasmic and myofibrillar protein solubility to colour and water-holding capacity in porcine longissimus muscle. Meat Sci. 52, 291-297.

25. Juncher, D., Rønn, B., Mortensen, E. T., Henckel, P., Karlsson, A., Skibsted, L. H., and Bertelsen, G. (2001) Effect of pre-slaughter physiological conditions on the oxidative stability of colour and lipid during chill storage of pork. Meat Sci. 58, 347-357.

26. Leach, L. M., Ellis, M., Sutton, D. S., McKeith, F. K., and Wilson, E. R. (1996) The growth performance, carcass characteristics, and meat quality of halothane carrier and negative pigs. J. Anim. Sci. 74, 934-943.

27. Lindahl, G., Henckel, P., Karlsson, A. H., and Andersen, H. J. (2006) Significance of early postmortem temperature and $\mathrm{pH}$ decline on colour characteristics of pork loin from different crossbreeds. Meat Sci. 72, 613-623.

28. Lonergan, S. M., Stalder, K. J., Huff-Lonergan, E., Knight, T. J., Goodwin, R. N., Prusa, K. J., and Beitz, D. C. (2007) Influence of lipid content on pork sensory quality within $\mathrm{pH}$ classification. J. Anim. Sci. 85, 1074-1079.

29. Lundström, K., Enfält, A. C., Tornberg, E., and Agerhem, A. 
(1998) Sensory and technological meat quality in carriers and non-carriers of the $\mathrm{RN}^{-}$allele in Hampshire crosses and in purebred Yorkshire pigs. Meat Sci. 48, 115-124.

30. Maddock, R. J., Bidner, B. S., Carr, S. N., McKeith, F. K., Berg, E. P., and Savell, J. W. (2002) Creatine monohydrate supplementation and the quality of fresh pork in normal and halothane carrier pigs. J. Anim. Sci. 80, 997-1004.

31. Mortensen, M., Andersen, H. J., Engelsen, S. B., and Bertram, H. C. (2006) Effect of freezing temperature, thawing and cooking rate on water distribution in two pork qualities. Meat Sci. 72, 34-42.

32. Murray, A. C., Jones, S. D. M., and Sather, P. (1989) The effect of preslaughter feed restriction and genotype for stress susceptibility on pork lean quality and composition. Can. J. Anim. Sci. 69, 83.

33. Offer, G. and Cousins, T. (1992). The mechanism of drip production: Formation of two compartments of extracellular space in muscle postmortem. J. Sci. Food and Agri. 58, 107116.

34. Offer, G. and Knight, P. (1988) The structural basis of the water-holding in meat. Part 1: General principles and water uptake in meat processing. In: Developments in meat science - 4, Lawrie, R. (ed), London: Elsevier Applied Science, p. 63.

35. Park, B. Y., Kim, J .H. Cho, S. H., Ha, K. H., Lee, S. H., Chio, C. H., Kim, D. H., Lee, J. M., Kim, Y. K., Ahn, J. N., and Hwang, I. H. (2007) Evidence of Significant Effects of Stunning and Chilling Methods on PSE Incidences. AsianAustr. J. Anim Sci. 20, 257-262.

36. Park, M. J., Jeong, J. Y., Ha, D. M., Park, J. W., Sim, T. G., Yang, H. S., Lee, C. Y., Joo, S. T., and Park, B. C. (2009) Relationships of the slaughter weight to growth performance and meat quality traits in finishing pigs fed a low-energy diet. J. Anim. Sci(Kor). 51, 135-142.

37. Pearson, A. M. and Dutson, T. R. (1985) Scientific basis for electrical stimulation. In: Advances in meat research (Vol 1), Electrical stimulation, Pearson, D. H. and Dutson, T. R. (eds), AVI Publishing Company, Westport CT, pp. 185-218.

38. Piedrafita, J., Christian, L. L., and Lonergan, S. M. (2001) Fatty acid profiles in three stress genotypes of swine and relationship with performance, carcass, and meat quality traits. Meat Sci. 57, 71-77.

39. Rees, M. P., Trout, G. R., and Warner, R. D. (2003) The influence of the rate of $\mathrm{pH}$ decline on the rate of ageing for pork. II: Interaction with chilling temperature. Meat Sci. 65, 805-
818.

40. Rosenvold, K. and Andersen, H. J. (2003) Factors of significance for pork quality - a review. Meat Sci. 64, 219-237.

41. Rule, D. C. (1997) Direct transesterification pf total fatty acids of adipose tissue, and of freeze-dried muscle and liver with boron-trifluoride in methanol. Meat Sci. 46, 23-32.

42. Savell, J. W., Mueller, S. L., and Baird, B. E. (2005) The chilling of carcasses. Meat Sci. 70, 449-459.

43. Shi-Zheng, G. and Su-Mei, Z. (2009) Physiology, affecting factors and strategies for control of pig meat intramuscular fat. Recent Patent on Food Nutr. Agri. 1, 59-74.

44. Tornberg, E. (2005) Effects of heat on meat proteins - Implications on structure and quality of meat products. Meat Sci. 70, 493-508.

45. Van Laack, R. L. J. M., Stevens, S. G., and Stalder, K. J. (2001) The influence of ultimate $\mathrm{pH}$ and intramuscular fat content on pork tenderness and tenderization. J. Anim. Sci. 79, 392-397.

46. Van Oeckel, M. J. and Warnants, N. (2003) Variation of the sensory quality within the $\mathrm{m}$. longissimus thoracis et lumborum of PSE and normal pork. Meat Sci. 63, 293-299.

47. Wood, J. D. and Enser, M. (1997) Factors influencing fatty acids in meat and the role of antioxidants in improving meat quality. Brit. J. Nutr. 78, S49-S60.

48. Wood, J. D., Enser, M., Fisher, A. V., Nute, G. P., Sheard P. R., Richardson, R. I., Hughes, S. I., and Whittington, F. M. (2008) Fat deposition, fatty acid composition and meat quality: A review. Meat Sci. 78, 343-358.

49. Wood, J. D., Enser, M., Fisher, A. V., Nute, G. R., Richardson, R. I., and Sheard, P. R. (1999) Manipulating meat quality and composition. Proceed. Meeting Nutr. Soc. 58, 363370.

50. Yasosky, J. J., Aberle, E. D., Peng, I. C. Mills, E. W., and Judge, M. D. (1984) Effects of $\mathrm{pH}$ and time of grinding on lipid oxidation of fresh ground pork. J. Food Sci. 49, 15101512.

51. Young, O. A., West, J., Hart, A. L., and van Otterdijk, F. F. H. (2004) A method for early determination of meat ultimate pH. Meat Sci. 66, 493-498.

52. Zhang, S., Knight, T. J., Stalder, K. J., Goodwin, R. N., Lonergan, S. M., and Beitz, D. C. (2007) Effects of breed, sex, and halothane genotype on fatty acid composition of pork longissimus muscle. J. Anim. Sci. 85, 583-591.

(Received 2009.10.12/Revised 1st 2009.12.16, 2nd 2009.12.18/Accepted 2009.12.18) 